\title{
Laicidade e Acordo Brasil-Santa Sé
}

\section{Laicity and Agreement Brazil-Holy See}

\section{Genacéia da Silva Alberton*}

\section{RESUMO}

A laicidade do Estado brasileiro é direito fundamental que confere a liberdade religiosa, conteúdo democrático da sociedade. O Acordo Brasil-Santa Sé apresenta-se como instrumento de relacionamento Igreja-Estado. Dois temas relevantes para o laicato, que fazem parte do Acordo são o ensino religioso confessional e a nulidade matrimonial canônica com efeito civil. O fortalecimento do laicato exigirá uma constante atualização e religiosidade madura, sedimentada no diálogo interno que dê suporte à atuação política dos leigos, sujeitos eclesiais, no Estado, mantendo o compromisso social, com prevalência de ações que visem ao bem comum e à dignidade humana na busca da santificação pessoal e comunitária.

Palavras-chave: Laicidade. Acordo Brasil-Santa Sé. Laicato.

\section{ABSTRACT}

The laicity of the State's fundamental law which grants religious freedom, democratic society content. The agreement Brazil-Holy See presents itself as an instrument of State-Church relationship. Two themes relevant to the laity, who are part of the agreement are the denominational religious teaching and the nullity of marriage with civil effect canonical. The strengthening of the laity will require a constant update and mature religiosity, sedimented in the internal dialogue that supports political action of the laity in the State, keeping the social commitment, with prevalence of actions aimed at the common good and human dignity in the pursuit of personal sanctification and the community.

Keywords: Laicity. Brazil. Agreement-Holy See. Laity.

\footnotetext{
* Desembargadora do Tribunal de Justiça do Rio Grande do Sul. É Doutora em Direito pela UNISINOS (2003), Mestre em Linguística Aplicada (1977) e em Direito (1992) pela PUCRS. Bacharel e Mestre em Teologia também pela PUCRS (2012). Jubilada como Professora de Processo Civil pela UNISINOS.<gsa@tjrs.jus.br>
} 


\section{INTRODUÇÃO}

A Igreja no Brasil enfrenta grande desafio na medida em que a sociedade passa por muitas mudanças sociais, com a prevalência de multiplicidade de credos; aumento acelerado da violência; ineficiência das políticas públicas; crise ética na política.

O Acordo Brasil-Santa Sé, por sua vez, pelo que se pode perceber empiricamente, é desconhecido da grande maioria dos brasileiros, mesmo católicos. Cumpre refletir, portanto, qual a importância de um Estatuto Jurídico da Igreja Católica. Restam três caminhos: aplicá-lo na sua integridade; suscitá-lo naquilo que for específico de proteção à instituição da Igreja ou deixá-lo como letra morta, guardado e empoeirado, destino de algumas leis em nosso País.

Estamos no Ano do Laicato e, segundo o Papa Francisco, o que se deseja é fazer crescer a consciência da identidade e a missão dos leigos na Igreja como "sal da terra e luz do mundo" (Mt 5,13-14). A Igreja se abre para as urgências do mundo, uma Igreja em "saída" (EG 20).

As estruturas institucionalizadas do mundo secular estão afinadas ao poder vertical e têm resistência à abertura. Muito tem sido feito, tanto na Igreja como nas instituições de poder, mas é preciso avançar, sem temer a laicidade. Cumpre priorizar a pessoa e a vida.

Considerando a dimensão do tema laicidade e o Acordo Brasil-Santa Sé, o assunto será estruturado em quatro eixos: a) semântico; b) histórico; c) prático; d) perspectivas.

No aspecto semântico, serão destacadas as distinções entre secularização/ secularidade, laicidade/laicismo; no histórico, será apresentada uma síntese da laicidade no Brasil e sua importância atual para a democracia; no eixo prático, serão analisados os aspectos relevantes do Acordo Brasil - Santa Sé para os leigos e, nas perspectivas, serão abordados os rumos do laicato.

Estamos em tempo de mudança e o desafio do laicato é ser efetivo sujeito eclesial, consciente de sua missão no mundo e na Igreja.

\section{SECULARIZAÇÃO E SECULARISMO, LAICIDADE ESTATAL E LAICISMO}

É possível, ao nos referirmos a secular e à secularização, fazer uma contraposição entre espaço do mundo e espaço restrito ao religioso.

Quando se alia a ideia de secular ao Estado, a relação entre secularidade e laicidade se evidencia. Catroga refere que a palavra saeculum aplicada na Vulgata de São Jerônimo, foi usada para traduzir kósmos na acepção de tempo presente em oposição à eternidade, o "reino", caracterizando o que era do mundo. No cristianismo, segundo o mesmo autor, ficou relacionada à distinção entre a categoria do clero e dos crentes ${ }^{1}$.

A secularização, em síntese, se apresenta como um processo fortalecido com a saída da sociedade do domínio do religioso, perda do significado social da religião frente à modernidade e à modernização, enquanto conjunto de mudanças operadas nas esferas políticas, econômica e social desde a Revolução Francesa de 1789 à Revolução Industrial ${ }^{2}$. Essa secularização não se apresenta como efetiva perda do sentido religioso, mas uma crise de fé, com ênfase à racionalização do mundo e enfraquecimento do sentido do transcendente ${ }^{3}$.

\footnotetext{
Cf. CATROGA, F. Entre deuses e césares: secularização, laicidade e religião civil, p. 49.

${ }^{2}$ Cf. BOBBIO, N. et al. Dicionário de Política, p. 278.

${ }^{3}$ Cf. FAZIO, M. Storia delle idee contemporanee: una lettura del processo di secolarizzazione, p. 13.
} 
Aliás, Mariano Fazio faz uma distinção entre a secularização absoluta e a relativa ou cristã. Distingue a secularização com a autonomia absoluta do homem e do mundo e a que toma consciência da autonomia relativa do temporal, o que ele denomina de desclericalização ou secularização cristã ${ }^{4}$. Por isso, sem preocupação em absoluto ou relativo, Charles Taylor prefere o termo "secularidade"s.

Em relação às instituições, no caso, o Estado, em decorrência da secularidade, ele se apresenta livre de compromisso com Deus. Assim, as Igrejas estão separadas das estruturas políticas ${ }^{6}$.

Observando as condições de fé, a secularidade implica em uma mudança social em que acreditar em Deus é apenas uma possibilidade, sendo necessário um movimento que favoreça o crescimento da fé. Por isso, o Papa Bento XVI, na Carta Apostólica Ubicumque et Semper, em que foi instituído o Pontifício para a promoção da Nova Evangelização, apontou a crescente secularização e as novas seitas como fatores de impacto a exigir uma nova evangelização para "o crescimento de uma fé límpida e profunda".

E Papa Francisco, na sua mensagem aos participantes do Congresso dos Institutos Seculares Italianos por ocasião dos 70 anos da Constituição Apostólica Provida Mater Ecclesia, destacou a necessidade de um compromisso cristão na vida social:

[...] a novidade e a fecundidade dos Institutos Seculares consiste em conjugar consagração e secularidade, praticando um apostolado de testemunho, de evangelização - especialmente para os presbíteros - e de compromisso cristão na vida social - especialmente para os leigos, àquele se acrescenta a fraternidade que, sem ser determinada por uma comunidade de vida, contudo é verdadeira comunhão .

Passamos pela era do vazio, império do efêmero, na visão de Gilles Lipovetsky, ou de uma sociedade líquida na visão de Zygmunt Bauman, motivo pelo qual se supera a denominada pós-modernidade onde ocorre a ampliação da esfera da autonomia subjetiva e multiplicam-se as diferenças individuais e os indivíduos esvaziam-se de "sua substância transcendente". Os indivíduos têm a possibilidade de assumir responsabilidade ou não, autocontrolar-se ou deixar-se levar ${ }^{8}$. Portanto, relacionando com a religião, se não houver uma maturidade religiosa, aumenta a possibilidade de deixar-se levar.

Importante é destacar que esse processo de secularidade, na visão do Estado, está diretamente relacionado à laicidade que representa, em termos de democracia, uma liberdade para o cidadão a quem são conferidos direitos constitucionais e infraconstitucionais independentemente da crença religiosa. É uma garantia de não exclusão. Nesse sentido é que se diz que o Estado brasileiro é laico. Fica inibida a atuação da Igreja no espaço público, como forma de intervenção, mas a sua manifestação não é vedada na medida em que vem representar uma parcela do corpo social.

Longe de afastá-lo da realidade secular como cidadão, a religião confere ao leigo maior responsabilidade no meio social, responsabilidade para com o bem público, para com a casa comum, não por uma filiação política, ou ideológica, mas por uma filiação espiritual, pois somos todos irmãos de um mesmo Pai.

\footnotetext{
${ }^{4}$ Cf. FAZIO, M. La autonomia de las realidades terrestres en la Gaudium et Spes, p. 640.

${ }^{5}$ Cf. TAYLOR, C. Uma era secular.

${ }^{6}$ Não há secularidade pura, pois ainda se admitem feriados religiosos, não só católicos, mas são respeitados, por exemplo, o Ramadan, dos muçulmanos e o Yon Kipur, Dia do Perdão, dos judeus.

${ }^{7}$ FRANCISCO, Mensagem aos participantes no congresso dos institutos seculares italianos por ocasião da constituição apostólica Provida Mater Ecclesia (23.10.2017).

${ }^{8}$ Cf. LIPOVETSKY, G. A era do vazio: ensaios sobre o individualismo contemporâneo.
} 
Numa visão perversa da laicidade se apresenta o laicismo, que não se limita a admitir a autonomia da esfera civil em relação à religiosa. Ele não considera a religião como um fato positivo na vida pública, mas, sim, como um elemento nocivo e que deve ser relegado a uma esfera exclusivamente privada. Assim sendo, a política deve libertar-se de qualquer contaminação com a religião e os crentes são colocados em um grupo à parte9 .

Como consequência, como lembra Possenti, o laicismo é mais profundo e universal, de tal forma que pode conduzir a uma restrição da liberdade religiosa ${ }^{10}$. De qualquer forma, mantém-se a conotação de intolerância antirreligiosa enquanto a laicidade tem uma referência à liberdade de religião e de consciência, assimilando a laicidade à noção de respeito e tolerância.

A laicidade do Estado é princípio fundamental da ordem constitucional brasileira que impõe a separação entre Igreja e Estado, reconhece a liberdade religiosa e assegura igualdade dos cidadãos, garantindo a plena liberdade de consciência e de culto.

Como critério metodológico, a laicidade induz o respeito à realidade e à racionalidade que podem ser usados por crentes e não crentes sobre valores da vida comum e dos fundamentos jurídicos e políticos para a convivência civil, levando ao diálogo e à responsabilidade.

Como consequência, a laicidade se apresenta como disponibilidade entre razões seculares e fés religiosas, reconhecendo-se reciprocamente ${ }^{11}$. Torna-se possível, assim, chegar a alguns objetivos fundamentais e participar de discussões especialmente quando se trata de proteção da pessoa e questões fundamentais envolvendo a questão da vida.

Recentemente Dom Ricardo Hoepers, bispo de Rio Grande, participou, em maio do corrente ano, de um seminário na Câmara de Deputados que trouxe como tema a Arguição de Descumprimento de Preceito Fundamental (ADPF) 442 sobre o aborto, organizado pela Comissão de Seguridade Social e Família da Câmara e promovido pelas Comissões de Defesa dos Direitos das Pessoas com Deficiência e a de Direitos Humanos e Legislação Participativa do Senado Federal.

Participou também Dom Ricardo, em nome da CNBB, de audiência pública convocada pela Ministra Rosa Weber, relatora da Ação por Descumprimento de Preceito Fundamental (ADPF) 442, apresentada pelo PSOL, com assessoria técnica do Instituto de Bioética Anis, fazendo forte manifestação a favor da vida contra a descriminalização do aborto até a $12^{\mathrm{a}}$ semana de gestação ${ }^{12}$.

Dar um espaço para a laicidade se torna indispensável. Quanto mais se abrir espaço à exposição de ideias e argumentos, mais nos afastamos de atitudes fundamentalistas. Por isso, ela deve ser valorizada como uma dimensão da própria natureza humana. A laicidade implica, pois, em uma disponibilidade à cooperação e à escuta ${ }^{13}$ e não se coaduna com o laicismo que se constitui em uma degeneração ideológica negativa, especialmente anticlerical ${ }^{14}$.

\section{LAICIDADE NO ESTADO BRASILEIRO NA PERSPECTIVA HISTÓRICA}

Sem juízo de valor, pretendemos demonstrar, de forma sintética, o sentido da laicidade em relação à Religião Católica no Brasil e a sua importância para a própria afirmação consciente do catolicismo.

\footnotetext{
${ }^{9}$ Cf. POSSENTI, V. Le ragioni della laicità. Soveria Mannelli [Calabria]: Rubbettino, 2007, p. 6.

${ }^{10} \mathrm{Cf}$. POSSENTI, V. Le ragioni della laicità, p. 32.

${ }^{11} \mathrm{Cf}$. POSSENTI, V. Le ragioni della laicità, p. 38.

${ }^{12}$ Cf. CLARO, D. Vamos defender a vida: convoca Dom Ricardo Hoepers sobre aborto.

${ }^{13}$ Cf. SAVAGNONE, G. Dibattito sulla laicità: alla ricerca di una identità, p. 15.

${ }^{14} \mathrm{Cf}$. SAVAGNONE, G. Dibattito sulla laicità, p. 17.
} 
Desde o início da colonização portuguesa até o advento da República, Estado e Igreja Católica integravam a ordem política brasileira. O Império era confessional. Aponta Paulo Lobo que apesar da inspiração iluminista, a Constituição Imperial de 1824, estabeleceu no seu art. 50:

A religião Católica Apostólica Romana continuará a ser a religião do Império. Todas as outras religiões serão permitidas com seu culto doméstico ou particular, em casas para isso destinadas, sem forma alguma exterior de templo.

Nesse período, a religião católica permaneceu no espaço público, sendo que as demais manifestações religiosas ficavam adstritas ao privado ${ }^{15}$.

Fábio Carvalho Leite, ao discorrer sobre o laicismo na Primeira República do Brasil, afirma que, embora haja entendimento de que a Constituição de 1891 teria definido a separação entre Estado e religião, influenciado pela ideologia positivista e de que a Constituição de 1934, teria implementado um modelo de cooperação como reação católica ao laicismo, o país não deixara de ser majoritariamente católico. Como consequência, o quadro administrativo do Estado seria preenchido por católicos ${ }^{16}$.

Algumas posturas laicistas da Primeira República sinalizadas por Leite foram: ausência de menção a Deus no preâmbulo da Constituição; retirada de crucifixos e símbolos religiosos dos locais públicos em situações episódicas; secularização dos cemitérios; omissão no texto constitucional de compromisso de manutenção de relações diplomáticas entre Brasil e Santa Sé, assim como o caráter leigo do ensino público ${ }^{17}$.

A retirada de crucifixo ocorreu em Tribunais do Júri. Um episódio foi suscitado pelo pastor evangélico Miguel Ferreira, signatário de Manifesto Republicano, alegando a separação Igreja e Estado e sua liberdade de consciência. Porém, vindo a decidir sobre o assunto, Barão de Lucena, ministro do interior, indeferiu o pedido, caracterizando a conduta como fanática intolerância, posição mantida em outras instâncias do governo, Câmara dos Deputados e Senado Federal. Solicitada a entrega do crucifixo por autoridades católicas, em 1906, quando houve reposição da cruz, ressurgiu situação idêntica, sendo mantido o símbolo religioso ${ }^{18}$.

Mesmo havendo um modelo de laicidade, na prática, após a Constituição de 1934, manteve-se a colaboração entre Estado e religião, incluindo a possibilidade de ensino religioso em escolas públicas, cemitérios públicos confiados à administração confessional, símbolos religiosos em locais públicos, feriados religiosos, legação brasileira junto à Santa Sé19.

De 1937 a 1945 o Brasil viveu em regime ditatorial civil, mas a aproximação do Estado com a Igreja Católica se manteve tendo em vista que ainda se mantinha como a religião majoritária na população brasileira a católica.

\footnotetext{
${ }^{15} \mathrm{Cf}$. LOBO, P. O Estado laico é conquista de todos e das famílias.

${ }^{16} \mathrm{Cf}$. CARVALHO LEITE, F. O laicismo e outros exageros sobre a Primeira República no Brasil.

${ }^{17} \mathrm{Cf}$. CARVALHO LEITE, F. O laicismo e outros exageros.

${ }^{18}$ Cf. CARVALHO LEITE, F. O laicismo e outros exageros. Nota 2. Note-se situação semelhante ocorrida no Rio Grande do Sul de determinação de retirada de crucifixos e símbolos religiosos nos espaços públicos da Justiça gaúcha, em face da neutralidade do Estado, acolhendo pedido da Liga Brasileira de Lésbicas e outras entidades em recurso administrativo contra indeferimento inicial, encaminhado ao Conselho da Magistratura. Contra essa decisão houve recurso da Arquidiocese de Passo Fundo ao Conselho Nacional de Justiça que estabeleceu que a presença de crucifixo ou símbolos religiosos em um tribunal não afeta o Estado laico porque não induz nenhum indivíduo a adotar qualquer tipo de religião. Disponível em: $<$ https://www.acidigital.com/noticias/decisao-do-cnj-esclarece-crucifixo-em-prediosda-justica-nao-afeta-estado-laico-15362>. Acesso em 20.08.18. Sobre o tema: ALBERTON, G. da S. Laicidade na Relação Igreja-Estado e o Acordo Brasil-Santa Sé, p. 133-143. Houve decisão monocrática do Conselheiro Emmanoel Campelo como Relator, em 05.05.2016, julgando procedente os pedidos, tornando sem efeito o ato administrativo do Conselho Superior da Magistratura do Tribunal de Justiça do Estado do Rio Grande do Sul que determinou, de forma discriminatória, a retirada dos crucifixos (Ref. PCA no 0001418-80.2012.2.00.0000).

${ }^{19} \mathrm{Cf}$. GIUMBELLI, E. O fim da Religião - dilemas da liberdade religiosa no Brasil e na França, p. 242, apud CARVALHO LEITE, F. O laicismo e outros exageros.
} 
Após a derrubada de Vargas, a situação continuou inalterada. A Constituição de 1946 manteve direitos civis e políticos, estendendo ainda o direito de voto a todo o cidadão, homem ou mulher acima de 18 anos. Houve, nesse período, liberdade de imprensa e de organização política até 1964, quando se iniciou o período de repressão.

Durante esse período, a Igreja no Brasil ainda estava vivenciando a época pré e pós Vaticano II. Com a repressão militar, muitos religiosos ficaram a favor dos torturados e eram mal vistos como comunistas, marxistas ${ }^{20}$.

A nova ditadura militar (1964-1974) se apresentava como uma luta contra o comunismo pela preservação da sociedade capitalista. A censura à imprensa eliminou a liberdade de opinião, partidos, sindicatos, associações eram vigiadas pelo governo.

A partir de 1974, houve o início de abertura a direitos políticos, sendo que em 1978 o Congresso votou o fim do AI 5, extinguindo-se a censura prévia nos meios de comunicação e restaurada a possibilidade de habeas corpus para crimes políticos.

Em 1975 surgiram as CEBs. Os movimentos sindicais com a representatividade da CUT incentivavam as greves, resistindo à repressão, aliando-se a esses movimentos a Igreja Católica e a OAB.

Em 1985, ocorreu a morte de Tancredo Neves, quando estava sendo retomada a supremacia civil no país. Entretanto, o movimento de abertura democrática continuou sendo, em 1988, aprovada a constituição cidadã que manteve a laicidade do Estado, com previsão constitucional do casamento religioso com efeito civil no Art. $226 \S 2$ o 21.

Fortalecida a cidadania, aberto espaço à democracia, a Igreja no Brasil não tem mais, na opressão, um estímulo à atuação. Vê-se, assim, na contingência de encontrar caminhos de uma nova evangelização ${ }^{22}$.

No ano de 2015, instalada uma instabilidade política, viu-se o aumento do desiquilíbrio social, aumento do desemprego, tendência à redução de rendimentos. No movimento da nova evangelização ${ }^{23}$ a partir do interno da Igreja, com uma comunidade de fé vida, agrega-se a ética do cuidado ${ }^{24}$.

O Papa Francisco nos incita a sair do individualismo, voltar-se à alteridade: "é necessário voltar a sentir que precisamos uns dos outros, que temos uma responsabilidade para com os outros e o mundo, que vale a pena ser bons e honestos"25.

A esse movimento dos leigos o Papa Francisco convida os bispos, especialmente os latino-americanos, a aprender a escutar e conhecer o Povo de Deus, dando-lhe a

\footnotetext{
${ }^{20}$ A defesa de muitos religiosos em prol dos pobres veio a colocá-los sob mira militar, taxados como comunistas ou marxistas. Essa resistência foi nutrida pelas ideias desenvolvidas nas Conferências Episcopais Latino-Americano e Caribenha de Medellín, em 1968 e Puebla em 1979, a teologia da libertação passou a ser, no Brasil, suporte para a atuação cristã resistente. Cf. LÖWY, M. A guerra dos deuses: religião e política na América Latina, p. 111.

21 “Art. 226. A família, base da sociedade, tem especial proteção do Estado. [...] § 2 o O casamento religioso tem efeito civil nos termos da lei” (BRASIL, Constituição Federal de 1988).

${ }^{22}$ No discurso pronunciado em Puebla, afirmou João Paulo II: "1.2. De vós, pastores, os fiéis de vossos países esperam e reclamam antes de tudo uma cuidadosa e zelosa transmissão de verdade sobre Jesus. Esta se encontra no centro da evangelização e constitui seu conteúdo essencial: 'Não há evangelização verdadeira enquanto não se anunciar o nome, a vida, as promessas, o reino, o mistério de Jesus de Nazaré, Filho de Deus' [EN 22]" (JOÃO PAULO II. Discurso inaugural da III Conferência Geral do Episcopado Latino-Americano em Puebla). Em Santo Domingo na Carta de João Paulo II afirmava o Papa: “6. A nova evangelização não consiste num 'novo evangelho', que surgiria sempre de nós mesmos, da nossa cultura ou da nossa análise, sobre as necessidades do homem, por isso não seria 'evangelho' mas pura invenção humana e a salvação não se encontraria nele" (JOÃO PAULO II. Discurso inaugural da IV Conferência Geral do Episcopado Latino-Americano e Caribenho em Santo Domingo).

${ }_{23}$ "Solo una nuova evangelizzazione può assicurare la crescita di una fede limpida e profonda, capace di fare di queste tradizioni una forza di autentica liberta" ["Só uma nova evangelização pode assegurara o crescimento de uma fé límpida e profunda, capaz de fazer dessas tradições uma força de autêntica liberdade"] (INTROVIGNE, M. Tu sei Pietro. Benedetto XVI contro la dittatura del relativismo, p. 291).

${ }^{24}$ Cf. FRANCISCO. Carta Encíclica Laudato Sì sobre o cuidado da casa comum (24.05.2015).

${ }^{25}$ Cf. FRANCISCO. Laudato Si, n.229.
} 
importância que merecem. Na Assembleia do CELAM, em 2017, em El Salvador, o Papa Francisco, inspirado na padroeira do Brasil, no ano em que foi celebrado os 300 anos de sua aparição, ao ressaltar o encontro da Mãe Aparecida, suja de lama, exortou os bispos a não terem medo de arriscar e de se comprometerem com os "sujos" e afirmou:

Prefiro uma Igreja acidentada, ferida e enlameada por ter saído pelas estradas, a uma Igreja enferma pelo fechamento e a comodidade de se agarrar às próprias seguranças ${ }^{26}$.

Segundo o resultado de pesquisa do IBGE 2010, o número de católicos caiu para $64,6 \%{ }^{27}$. E a grande tarefa é a de formação de pensadores e de pessoas que estejam em níveis de decisão, evangelizando os "novos areópagos"28: universitário, comunicação, empresários, políticos e formadores de opinião, dirigentes sindicais e líderes comunitário ${ }^{29}$.

\section{ACORDO BRASIL-SANTA SÉ ${ }^{30}$ E SUA IMPORTÂNCIA: ENSINO RELIGIOSO E A NULIDADE MATRIMONIAL}

Para dar condições à efetiva missão da Santa Sé, no espaço internacional, o Tratado Lateranense, de 1929, reconheceu a plena soberania da Santa Sé sobre o Vaticano. Logo, Santa Sé é Estado, reunindo os requisitos para a sua identificação, ou seja, território, população, governo e capacidade jurídica para se relacionar com outros sujeitos de Direito Internacional.

Conforme apontei em obra sobre o tema ${ }^{31}$, embora o Código de Direito Canônico, no Cân. 113, § 1ํㅡㄹ afirme que a Igreja Católica e a Santa Sé são pessoas morais ${ }^{32}$ pela própria ordenação divina, apenas a Santa Sé é sujeito internacional. Por isso, fala-se em Diplomacia da Santa Sé ou Pontifícia e o representante da Santa Sé mantém o título de Núncio Apostólico ${ }^{33}$.

Veja-se que também sob a denominação de Santa Sé, no Código de Direito Canônico, inclui-se o Romano Pontífice, a Secretaria de Estado, o Conselho para negócios públicos de Igreja e demais organismos da Cúria Romana, conforme dispõe o Cân. 361. Nos termos do Cân. 363, o Legado do Romano Pontífice representa o Papa junto às Igrejas Particulares, Estados e Autoridades públicas a quem sejam enviados. Mas também os Delegados e Observadores junto a Conselhos Internacionais atuam como representantes da Sé Apostólica. Mantém-se a visão da Igreja comunhão, abrindo espaço para a atuação do Núncio não apenas do ponto de vista diplomático em relação às autoridades estrangeiras, mas exercendo função intereclesial ${ }^{34}$.

\footnotetext{
${ }^{26}$ FRANCISCO, Exortação Apostólica Pós-Sinodal Evangelii gaudium, 49.

${ }^{27}$ Cf. AZEVEDO, R. O IBGE e a Religião.

${ }^{28} \mathrm{Cf}$. V CONFERÊNCIA GERAL DO EPISCOPADO LATINO-AMERICANO E DO CARIBE, Aparecida. Documento de Conclusão, n. 491

${ }^{29} \mathrm{Cf}$. CNBB, Diretrizes Gerais da Ação Evangelizadora na Igreja no Brasil 2015-2019, n. 118.

${ }^{30}$ Decreto no 7.107, de 11 de fevereiro de 2010, promulga o Acordo entre o Governo da República Federativa do Brasil e a Santa Sé relativo ao Estatuto Jurídico da Igreja Católica no Brasil, firmado na Cidade do Vaticano, em 13 de novembro de 2008.

${ }^{31}$ ALBERTON, G. da S. Laicidade na Relação Igreja-Estado. Cap. II, item 4.

${ }^{32}$ São pessoas morais porque sua personalidade e existência jurídica são recebidas de seu fundador. São pessoas pré-jurídicas porque pessoas de natureza espiritual, religiosa e humanitária. Santa Sé e Igreja Católica constituem uma realidade de natureza espiritual porque postas por Cristo; cf. SOUZA, S. C. de. A Santa Sé e o Estado da Cidade do Vaticano: distinção e complementaridade, p. 291.

33 “Ao ser designado o Núncio Apostólico, confere-se ao Representante Papal a dignidade de Arcebispo para que ele possa exercer a plenitude de suas funções junto às Igrejas Particulares" (BALDISSERI, L. Diplomacia Pontifícia-Acordo Brasil-Santa Sé. Intervenções, p. 25).

${ }^{34} \mathrm{O}$ múnus do Núncio está elencado nos Cân. 364-365 do Código de Direito Canônico.
} 
O uso do termo Acordo em vez de Concordata ${ }^{35}$ não faz diferença em termos jurídicos porque os ambos têm força de tratado internacional. Por outro lado, o escopo do Acordo Brasil - Santa Sé foi de recolher normas já existentes para facilitar as relações entre as instituições: "Nesse sentido, o subtítulo 'Estatuto Jurídico da Igreja Católica no Brasil' tem sua relevância e os preceitos do direito interno ganham força redobrada em virtude da aquisição da dimensão internacional"36.

O denominado Estatuto Jurídico da Igreja Católica no Brasil, elaborado em forma de Acordo entre Santa Sé e a República Federativa do Brasil foi assinado em 13 de novembro de 2008, no Vaticano, na presença do Presidente da República do Brasil e do Secretário do Estado do Vaticano.

Houve aprovação pelo Congresso Nacional do Brasil em 7 de outubro de 2009, aprovado que fora na Câmara dos Deputados em 27 de agosto de 2009. Celebrada a Troca dos Instrumentos de Ratificação no Vaticano, foi promulgado pelo Presidente Luis Inácio Lula da Silva em 11 de fevereiro de 2010, sendo publicado no Diário Oficial da União em 12 de fevereiro de 2010. Logo, todas as tramitações diplomáticas foram observadas, sendo documento legítimo no campo do direito internacional.

O Acordo Brasil-Santa Sé se apresenta como um instrumento de relacionamento Igreja - Estado em que se admite a tradição cultural do país, preservando a liberdade cidadã. É indiscutível que houve um fortalecimento da jurisdição eclesiástica e aí identifico o grande avanço na relação de cooperação do Brasil com a Igreja. Acrescentese que não há de falar em privilégios visto que não há prevalência da Igreja Católica em relação a outras, mas apenas condições para o exercício da missão da Igreja na sociedade brasileira.

Importante esclarecer que, havendo conflito entre Constituição e Tratado, sendo a mesma declarada, o ato internacional não prevalecerá ${ }^{37}$. Por esse motivo as impugnações ao Acordo poderão ser feitas por Ação Direta de Inconstitucionalidade (ADIN) ou Arguição de Descumprimento de Preceito Fundamental (ADPF). Não sendo reconhecida a inconstitucionalidade ou o descumprimento de preceito fundamental o artigo impugnado permanece no Acordo, incorporado ao sistema jurídico interno.

$\mathrm{O}$ art. $1^{\circ}$ do Acordo Brasil - Santa Sé reconhece as relações diplomáticas e seus representantes, no caso o Núncio Apostólico acreditado na República Federativa do Brasil e Embaixador do Brasil, a junto à Santa Sé38.

Logo, a Igreja Católica, pelo art. $2^{\mathrm{O}}{ }^{39}$, tem o direito de desempenhar Missão Apostólica $^{40}$, garantindo o exercício público de sua atividade nos termos da lei brasileira que prevê no art. 5ำ, inc. VI da Constituição Federal a inviolabilidade à liberdade de consciência e de crença ${ }^{41}$.

\footnotetext{
${ }^{35}$ Segundo Baldisseri, ao longo da história, as concordatas visavam pôr fim a dissensões entre Igreja e os poderes civis. A partir da concordata napoleônica de 1801, deu-se início às concordatas modernas que podem ter conteúdo espiritual, como os que cuidam de liturgia como a Concordata com o Equador, de 1862; conteúdo temporal ou misto. As concordatas de temas temporais podem disciplinar taxações, como a Concordata com a Costa Rica, em 1852. Os temas mistos envolvem questões de ordem temporal e espiritual, como as que envolvem casamento e educação. Após o Concílio Vaticano II, as concordatas têm sido elaboradas visando uma sana cooperatio (BALDISSERI, L. Diplomacia Pontifícia-Acordo, p. 87-88).

${ }^{36}$ Cf. BALDISSERI, L. Diplomacia Pontificia-Acordo, p. 61.

${ }^{37}$ Cf. DOLINGER, J. Direito internacional privado, p. 248.

${ }^{38}$ As Altas Partes Contratantes continuarão a ser representadas, em suas relações diplomáticas, por um Núncio Apostólico acreditado junto à República Federativa do Brasil e um(a) Embaixador(a) do Brasil acreditado(a) junto à Santa Sé, com as imunidades e garantias asseguradas pela Convenção de Viena sobre Relações Diplomáticas, de 18 de abril de 1961, e demais regras internacionais.

${ }_{39}$ “Art. 2ㅇ A República Federativa do Brasil, com fundamento no direito de liberdade religiosa, reconhece à Igreja Católica o direito de desempenhar a sua missão apostólica."

${ }^{40}$ Cf. OLIVEIRA, H. J. S. C. Art. 2o Direito de Desempenhar a Missão Apostólica, p. 107-136.

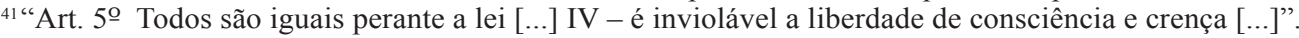




\subsection{O ensino religioso}

Tendo em vista a relevância do tema, passarei a examinar a questão do ensino religioso na perspectiva do Acordo Brasil -Santa Sé.

Foi questionada a constitucionalidade do art. 11 do Acordo ${ }^{42}$ em vista da laicidade do Estado. O Procurador-Geral da República, em exercício, em 30 de julho de 2010, propôs ação direta de inconstitucionalidade e decisão de interpretação conforme a Constituição do art. 11, §1ํㅡㄹ em relação ao Acordo entre a República Federativa do Brasil e a Santa Sé, denominada Estatuto Jurídico da Igreja Católica no Brasil publicada pelo Decreto no 7.107/2010. O objetivo era ver determinado que o ensino religioso em escolas públicas só pode ser não-confessional ou declarada a inconstitucionalidade do Acordo, especialmente pelo que consta no art. 11, §1으, do Acordo Brasil- Santa Sé (ADIN 4439) ${ }^{43}$.

Em face do princípio da laicidade do Estado (Constituição Federal, art. 19, I) ${ }^{44}$ e a previsão constitucional de que o ensino religioso é de matrícula facultativa nas escolas públicas de ensino fundamental (art. 210, § $1^{\circ}$ ) é questionada a disposição do art. 11, $\S 1$, do Acordo. Segundo consta na petição, não se pode admitir que "se transforme a escola pública em espaço de catequese e proselitismo religioso, católico ou de qualquer outra confissão".

Na obra Laicidade e ensino religioso no Brasil ${ }^{45}$, Débora Dinis destaca que, não havendo neutralidade estatal no ensino interconfessional, para compatibilizar o caráter laico do Estado brasileiro com o ensino religioso nas escolas públicas, o modelo seria o não confessional, incluindo posições não religiosas, como o ateísmo e o agnosticismo.

Pondera também o fato de que os professores deveriam ser do ensino público e não vinculados a igrejas ou confissões religiosas. Estaria, dessa forma, sendo observado o princípio da laicidade do Estado e observado o Plano Nacional de Direitos Humanos que estabelece, como objetivo estratégico, o respeito às diferentes crenças, liberdade de culto e garantia da laicidade do Estado.

Tal proposta, estaria em conformidade com a interpretação do art. 33 da Lei 9394/96, Lei de Diretrizes e Bases da Educação Nacional (LDBEN) ${ }^{46}$.

Com relação ao art. 11, § 1ํ, do Acordo Brasil-Santa Sé a Autora pondera que, para observar o princípio da laicidade estatal, seria necessário suprimir do referido artigo do Acordo, a expressão "católico e de outras confissões religiosas".

\footnotetext{
42 “A República Federativa do Brasil, em observância ao direito de liberdade religiosa, da diversidade cultural e da pluralidade confessional do País, respeita a importância do ensino religioso em vista da formação integral da pessoa. $§ 1 \stackrel{0}{0}$ : O ensino religioso, católico e de outras confissões religiosas, de matrícula facultativa, constitui disciplina dos horários normais das escolas públicas de ensino fundamental, assegurado o respeito à diversidade cultural religiosa do Brasil, em conformidade com a Constituição e as outras leis vigentes, sem qualquer forma de discriminação".

${ }^{43}$ SUPREMO TRIBUNAL FEDERAL. Acordo Brasil-Santa Sé-ADIN 4439. A CNBB foi admitida na causa como amicus curiae. Também ingressaram como intervenientes a Conferência dos Religiosos do Brasil (CRB), Associação Nacional de Educação Católica do Brasil (ANEC), Grande Loja Maçônica do Estado do Rio de Janeiro (GLMERJ), Fórum Nacional Permanente do Ensino Religioso (FONAPER).

44 “Art. 19. É vedado à União, aos Estados, ao Distrito Federal e aos Municípios: I - estabelecer cultos religiosos ou igrejas, subvencioná-los, embaraçar-lhes o funcionamento ou manter com eles ou seus representantes relações de dependência ou aliança, ressalvada, na forma da lei, a colaboração de interesse público".

${ }^{45}$ Cf. DINIZ, D.; LIONÇO, T.; CARRIÃO, V. Laicidade e ensino religioso no Brasil. Brasília: UNESCO; Letras Livres; Fundação Universidade de Brasília; Editora UNB, 2010.

46 “Art. 33. O ensino religioso, de matrícula facultativa, é parte integrante da formação básica do cidadão e constitui disciplina dos horários normais das escolas públicas de ensino fundamental, assegurado o respeito à diversidade cultural religiosa do Brasil, vedadas quaisquer formas de proselitismo (Redação dada pela Lei 9.475, de 22.7.1997).

$\S 1$ o Os sistemas de ensino regulamentarão os procedimentos para a definição dos conteúdos de ensino religioso e estabelecerão as normas para a habilitação e admissão dos professores.

$\S 2^{\circ}$ Os sistemas de ensino ouvirão entidade civil, constituída pelas diferentes denominações religiosas, para a definição dos conteúdos do ensino religioso".
} 
Em relação ao ensino religioso, Baldisseri aponta o fato de o art. 11 do Acordo dispor, com base no direito à liberdade religiosa, a pluralidade confessional. Note-se que o ensino religioso para a formação integral da pessoa não se contrapõe à Constituição Federal do Brasil que, no art. 205, determina que o ensino religioso deva visar "ao pleno desenvolvimento da pessoa". Além do mais, o art. 210, §1ํ da Constituição Federal prevê o ensino religioso, de matrícula facultativa. E bem pondera Baldisseri que o ensino religioso "não pode ser entendido como alusivo a uma "religião genérica", aconfessional, indefinida, já que tal "religião" não existe. Seria pura abstração mental, sem correspondência na realidade da vida e da sociedade humana" 47.

Por outro lado, Célio Borja afirma que, no art. 19, inciso I, da Constituição Federal, não há a expressão "Estado laico". Há, sim, uma cláusula proibitória de subvencionamento, embaraçamento ou dependência relação Estado-igreja e uma disposição autorizativa de colaboração no interesse público e na forma da lei ${ }^{48}$.

De acordo com Célio Borja, o pedido, conforme formulado da ação direta de inconstitucionalidade, importa em modificação de cláusula de tratado por ato judicial o que não é admitido porque alteraria unilateralmente disposição convencional. De qualquer forma, se admitida a inconstitucionalidade, tornaria inoperante a disposição do Tratado embora o Brasil não possa modificá-lo.

Quanto ao ensino confessional de religião, argumenta que a confessionalidade está ínsita na garantia da liberdade de crença que a Constituição assegura como inviolável (Constituição Federal, art. 5o, VI), sendo a confessionalidade inerente à garantia do ensino de religião ${ }^{49}$.

Especificamente sobre o ensino religioso no Brasil, Débora Diniz, Tatiana Lionço e Vanessa Carrião escreveram obra sobre a questão do ensino religioso nas escolas públicas, com acento no caso brasileiro. Afirmam as autoras que a laicidade entendida como dispositivo político que organiza as instituições básicas do Estado com separação entre a ordem secular e os valores religiosos torna escola pública como espaço que atualiza a controvérsia dos conteúdos da laicidade.

Lembram que, no Brasil, o ensino religioso nas escolas públicas não é objeto de consenso democrático ${ }^{50}$. Há inexistência de habilitação de professores para o ensino religioso e a LDBEN, no seu art. 33, previa inicialmente as modalidades de ensino confessional e interconfessional, sendo posteriormente retiradas as duas modalidades ${ }^{51}$.

Destacam as Autoras que a Lei no 9.475/1997 deu nova redação à LDBEN e foi relatada pelo então deputado Padre Roque Zimmermann (PT/PR), sendo sinal de importância do tema para a Igreja Católica ${ }^{52}$.

É necessário ter presente que o Conselho Nacional de Educação resguardou às próprias instituições de ensino, a definição de conteúdo da disciplina, em parceria com

\footnotetext{
${ }^{47}$ BALDISSERI, L. Diplomacia Pontificia - Acordo Brasil-Santa Sé, p. 112.

${ }^{48}$ BORJA, C. Constitucionalidade do art. 11 do Acordo Brasil-Santa Sé, p. 304.

49 “A confessionalidade inerente à garantia do ensino de religião como disciplina do currículo normal das escolas públicas; proibir a transmissão das razões de crer importa embaraço inconstitucional da inviolabilidade da liberdade de crença e de expressão das ideais.” (BORJA, C. Constitucionalidade do art. 11, p.323).

${ }^{50}$ Cf. DINIZ, D.; LIONÇO, T. Educação e laicidade. In: DINIZ, D.; LIONÇO, T.; CARRIÃO, V. Laicidade e ensino religioso no Brasil, p. 13.

51 “Art. 33. O ensino religioso, de matrícula facultativa, é parte integrante da formação básica do cidadão e constitui disciplina dos horários normais das escolas públicas de ensino fundamental, assegurado o respeito à diversidade cultural religiosa do Brasil, vedadas quaisquer formas de proselitismo. (Redação dada pela Lei no 9.475, de 22.7.1997).

$\S 1^{\text {O }}$ Os sistemas de ensino regulamentarão os procedimentos para a definição dos conteúdos do ensino religioso e estabelecerão as normas para a habilitação e admissão dos professores.

$\S 2^{\mathrm{o}}$ Os sistemas de ensino ouvirão entidade civil, constituída pelas diferentes denominações religiosas, para a definição dos conteúdos do ensino religioso".

${ }^{52}$ Cf. DINIZ, D.; LIONÇO, T. Educação e laicidade, p. 15.
} 
grupos religiosos. Vê-se, portanto, que o sentido que o país laico dê ao religioso vai interferir na forma como torna possível essa manifestação no âmbito escolar.

Não se vislumbra, de fato, a alegada inconstitucionalidade do artigo 11 do Acordo. $\mathrm{Na}$ base de sentido da palavra "religião" está "religare", "religio", não se denotando abusivo o fato de ser visto o fenômeno religioso como prioritário na formação da juventude e observada determinada diretriz.

Na medida em que o ensino religioso continua sendo facultativo, não fere a laicidade estatal. O que não é possível é tornar a religião imbuída de laicidade a ponto de afastar o aspecto transcendental ${ }^{53}$. O respeito pela diversidade religiosa não se confunde com desorientação religiosa.

A Ação Direta de Inconstitucionalidade (ADIN 4439) promovida pela Procuradoria Geral da República teve por objeto o art. 33, caput e $\S \S 1$ o e 2o da Lei 9.394, de 20 de dezembro de 1996 (LDBEN) ${ }^{54}$ e o art. 11, § 1, do Acordo Brasil- Santa Sé relativo ao Estatuto Jurídico da Igreja Católica no Brasil ${ }^{55}$. O pedido era de que o Supremo Tribunal Federal procedesse à interpretação conforme a Constituição para declarar que o ensino religioso em escolas públicas só pode ser de natureza não confessional, com a proibição de admissão de professores como representantes das confissões religiosas.

Foi convocada audiência pública em 15 de junho de 2015 com representantes de diferentes confissões religiosas, inclusive a católica. E a demanda foi conhecida porque o Acordo Brasil - Santa Sé, promulgado pelo Decreto no 7.107/2010, constitui acordo internacional incorporado ao ordenamento jurídico brasileiro com "status" da lei ordinária. Foi reconhecido o dever do Estado em assegurar a liberdade religiosa e conservar posição de neutralidade no tocante às diferentes religiões sem privilegiar ou desfavorecer qualquer uma delas.

O art. 19, inc. I, da Constituição Federal, estabelece regra geral que deve reger as relações entre Estado e confissões religiosas, de onde se extrai o princípio da laicidade ${ }^{56}$. E o art. 210 da mesma Constituição, em relação ao ensino religioso, estabelece a facultatividade $^{57}$. Houve alteração do art. 33 da LDBEN pela Lei no 9.475 que estabeleceu a disciplina como parte integrante da formação básica do cidadão e excluiu a exigência de que o ensino religioso fosse ministrado sem onerar os cofres públicos. E constou no fundamento:

É essencial neste projeto é a proibição de quaisquer formas de doutrinação ou préstimo, ou seja, a catequese, a pregação, a iniciação nos fundamentos de determinado sistema religioso". Eliminada a alternativa do ensino religioso confessional, é dispensável a expressão "sem ônus para os cofres públicos ${ }^{58}$.

\footnotetext{
${ }^{53}$ Sobre o conceito de religião no Ocidente, ver SMITH, W. C. O sentido e o fim da religião. São Leopoldo: Sinodal, 2015, p. 27-56).

${ }^{54}$ “Art. 33. O ensino religioso, de matrícula facultativa, é parte integrante da formação básica do cidadão e constitui disciplina dos horários normais das escolas públicas de ensino fundamental, assegurado o respeito à diversidade cultural religiosa do Brasil, e de quaisquer formas de proselitismo (Redação dada pela Lei n.9475, de 22.7.1997).

$\S 1$ ○ Os sistemas e ensino regulamentarão os procedimentos para a definição dos conteúdos do ensino religioso e estabelecerão as normas para a habilitação e admissão dos professores.

$\S 2^{\mathrm{o}}$ Os sistemas de ensino ouvirão entidade civil, constituída pelas diferentes denominações religiosas, para a definição dos conteúdos do ensino religioso."

55 “Art. 11. [...] § 1으 O ensino religioso, católico e de outras confissões religiosas, de matrícula facultativa, constitui disciplina dos horários normais das escolas públicas de ensino fundamental, assegurado o respeito à diversidade cultural religiosa do Brasil, em conformidade com a Constituição e as outras leis vigentes sem qualquer forma de discriminação".

56"Art. 19. É vedado à União, aos estados, ao Distrito Federal e aos Municípios: I - estabelecer culturas religiosos ou igrejas, subvencionálos, embaraçar-lhes o funcionamento ou manter com eles ou seus representantes relações de dependência ou aliança, ressalvada, na forma da lei, a colaboração de interesse público".

57 “Art. 210. [...] § 1을 $\mathrm{O}$ ensino religioso, de matrícula facultativa, constituirá disciplina dos horários normais das escolas públicas de ensino fundamental".

${ }^{58}$ Disponível em: <http:www.stf.jus.br/portal/> autenticação sob o número 13686373.
} 
Sendo Relator da ADIN o Ministro Roberto Barroso, o mesmo manifestou-se pela procedência dos pedidos para assentar que o ensino religioso em escolas públicas somente pode ter natureza não confessional considerando a separação formal entre Estado e Igreja, a neutralidade estatal em matéria religiosa e a garantia da liberdade religiosa, tendo a CNBB atuado como amicus curiae.

A Ministra Cármen Lúcia, ao desempatar, destacou o respeito às opções religiosas e, por isso, não estaria se opondo à laicidade estatal, sendo facultativo, o ensino religioso confessional vindo a acompanhar a divergência iniciada pelo Ministro Alexandre de Moraes. E afastada, por maioria, a inconstitucionalidade em Plenário no dia 27 de setembro de 2017, passou o Ministro Alexandre de Moraes como relator.

Sobre o tema ensino religioso, trago aqui as percucientes reflexões do Padre Marcos Sandrini, Coordenador da Comissão de Educação e Cultura da CNBB/Sul 3, que faz uma distinção entre educação à fé, educação na fé e educação da fé. A educação à fé seria "preparação da pessoa para receber o dom da fé"; a educação na fé significa que a pessoa já acolheu o dom da fé, precisa apenas continuar se educando. E a educação da fé é "impossível”, pois se trata de um dom ${ }^{59}$.

Os processos educativos são mais eficazes na defesa e promoção da vida, como aponta o Pe. Sandrini. Importante, pois, é uma educação voltada ao intradisciplinar que abra à transcendência não se coadunando com a catequese, que tem seu espaço específico na família e nas Igrejas: "a escola não é lugar propício e adequado para a catequese, pois lhe fala a dimensão da comunidade. Isto reforça o dualismo fé/vida. Nesse sentido é que se pode e (talvez) se deva reforçar o ensino religioso na linha da religiosidade" 60 .

A aplicação do referido artigo do Acordo ainda ensejará muita discussão e preparação da própria Igreja que deverá colaborar na preparação de professores e de projetos que facilitem a relação fé e vida.

\subsection{Matrimônio canônico}

Outro artigo polêmico ${ }^{61}$ do Acordo Brasil - Santa Sé é o 12, que concebe efeitos civis do casamento religioso e homologação das sentenças ${ }^{62}$. Aparentemente não parece haver dificuldade visto que a Constituição Federal, no seu art. 226, §2º dá efeito civil ao casamento religioso. Porém, a dificuldade se apresenta pelas peculiaridades da sentença canônica em relação à legislação civil brasileira.

Note-se que a sentença afirmativa de declaração de nulidade matrimonial canônica deve ser confirmada, mediante homologação por órgão superior da Santa Sé, no caso, a Assinatura Apostólica, nos termos do art. 121 e seguintes do Pastor Bonus, Constituição

\footnotetext{
${ }^{59}$ Cf. SANDRINI, M. Ensino Religioso e Educação Humanista num Estado Leigo.

${ }^{60}$ SANDRINI, M. Ensino Religioso.

${ }^{61}$ Sobre as dificuldades enfrentadas na Itália na relação do matrimônio concordatário e a legislação civil do país, ver FINOCCHIARO, F. Dirito ecclesiastico. Bolonha: Zanichelli, 2017, p. 459-466.

${ }_{62}$ "Art. 12. O casamento celebrado em conformidade com as leis canônicas, que atender também às exigências estabelecidas pelo direito brasileiro para contrair o casamento, produz os efeitos civis, desde que registrado no registro próprio, produzindo efeitos a partir da data da sua celebração.

$\S 1$ 으 A homologação das sentenças eclesiásticas em matéria matrimonial, confirmadas pelo órgão de controle superior da Santa Sé, será efetuada nos termos da legislação brasileira sobre homologação de sentenças estrangeiras". Aponte-se que, pela primeira vez, em junho de 2013, o STJ homologou a nulidade de casamento religioso decretada pelo Vaticano com base no acordo Brasil e Santa Sé. Inicialmente, o marido pediu a nulidade do casamento religioso ao Tribunal Eclesiástico Interdiocesano de Vitória, acusando a mulher de pedofilia. A sentença deferitória foi confirmada pelo Tribunal de Aparecida (SP) e, depois, pelo Vaticano. Ao homologar a sentença estrangeira, o ministro Felix Fischer considerou que o pedido não ofende a soberania nacional, a ordem pública nem os bons costumes. O número do processo não foi divulgado em razão de sigilo judicial. Disponível em: < http://www.stj.gov.br/portal_stj/publicacao/engine.wsp?tmp. area $=398 \&$ tmp.texto $=110084>$. Acesso em: 19 jun. 2013 .
} 
Apostólica sobre a Cúria Romana. Em se tratando de sentença eclesiástica, homologada pela Assinatura Apostólica, tal sentença é considerada sentença estrangeira. Portanto, seguirá o prosseguimento de carta rogatória. A homologação pela República Federativa do Brasil, salvo regulamentação que venha a ocorrer, será feita pelo Superior Tribunal de Justiça (Constituição Federal, art. 105, I, alínea 'i') a quem cabe homologação de sentença estrangeira e concessão de Exequatur às cartas rogatórias.

Com a devida homologação será possível o encaminhamento para averbação no registro competente independentemente de ofício. Se houver qualquer entrave que exija medida judicial, o ingresso em juízo para cumprimento de sentença far-se-á perante a justiça federal (Constituição Federal, art. 109, inc. X).

Por outro lado, ainda há a questão da coisa julgada. Somente pode ser homologada a sentença transitada em julgado. Porém, o Cân. 1643 do Código de Direito Canônico determina que nunca passam em julgado causas sobre o estado das pessoas, aí incluídas as causas envolvendo o vínculo matrimonial, o que não foi alterado pela Carta Apostólica Mitis Iudex Dominus Iesus, do Papa Francisco sobre a Reforma do Processo Canônico para as Causas de Declaração de Nulidade do Matrimônio no Código de Direito Canônico. Atente-se que a segurança jurídica exige que, pelo menos formalmente, haja uma preclusividade ${ }^{63}$. Logo, não há de se falar em trânsito em julgado material ${ }^{64}$, nos termos da lei processual civil brasileira ${ }^{65}$.

Ao tratar do tema da coisa julgada no Direito Canônico, ressalta Eduardo Talamini que "talvez nenhum instituto no direito processual da Igreja revista-se de tantas peculiaridades, em contrastes com os modelos processuais laicos, como a coisa julgada" 66 .

A sentença passada em julgado "goza da certeza do direito, com a presunção que seja justa e verdadeira, não podendo ser mais diretamente impugnada" ${ }^{67}$. Note-se que, de acordo com o Cân. 1679, com as alterações promovidas pela Mitis Iudex Dominus Iesus, transcorridos os prazos estabelecidos nos Cân. 1630-1633, a sentença, que em primeiro lugar declarou a nulidade do matrimônio, torna-se executiva.

O tema é desafiador na lei nacional, mas não é novidade em relação à Santa Sé. Norma semelhante foi acordada no tratado realizado na Espanha. Ao discorrer sobre a questão, Patrícia Alzate Monroy destaca que não cabe ao juiz revisar a fundo a sentença canônica, mas apenas observar o que não contraria a ordem pública do Estado espanhol.

Também não precisa haver exatidão entre as causas de nulidade matrimonial canônica e a civil até mesmo porque o sistema canônico é antidivorcista e admite apenas a relação heterossexual, diversamente do civil ${ }^{68}$.

Portanto, precedentes trazem luzes à situação brasileira. Averbado o matrimônio canônico para efeito civil, a relação matrimonial pela natureza contratual civil se rege pelas normas civis.

Há, porém, ainda uma questão a ser refletida é se, homologada a sentença canônica pelo Supremo Tribunal de Justiça, poderia algum interessado ingressar com querella nullitatis. Entendo que, por se tratar da lei canônica especial, ela prevaleceria em relação

\footnotetext{
${ }^{63}$ Por analogia ao que o Superior Tribunal de Justiça em relação às sentenças norte-americanas, em que o carimbo de arquivamento (filed) faz prova de trânsito em julgado. V.g. SEC 6069, publicada em 16.12.2011, a mesma sistemática poderá ser efetivada em relação às homologações de sentença.

${ }^{64}$ Art. 502, do NCPC. Denomina-se coisa julgada material a autoridade, que torna imutável e indiscutível a decisão de mérito não mais sujeita a recurso.

${ }^{65}$ Cf. BRASIL, Código de Processo Civil, Art. 502.

${ }^{66}$ Cf. TALAMINI, E. Coisa julgada e sua revisão, p. 220.

${ }^{67}$ Cf. ARROBA CONDE, M. Direito processual canônico, p. 674. A "res iudicata" dá ensejo a actio judicati, concedido a quem é favorecido para pedir a execução de sentença. E a exceptio rei judicate, concedido às partes para impedir a introdução de causa nova.

${ }^{68} \mathrm{MONROY}$, P. A. Eficácia civil de las sentencias eclesiásticas matrimoniales.
} 
a eventual prazo decadencial da lei nacional, tendo em vista a relevância do matrimônio como sacramento. Entretanto, essa é apenas uma hipótese a título de argumentação.

Do ponto de vista prático, certamente ao profissional da área do Direito a escolha será pelo divórcio civil, ingressando com a nulidade matrimonial canônica apenas para o efeito religioso, visto que, na área cível terá espaço legal para solução de todas as questões decorrentes da dissolução do vínculo, incluindo a patrimonial, guarda de filhos, alimentos e demais disposições de reflexo familiar.

Percebe-se, pela leitura de acórdãos do Supremo Tribunal Federal a quem cabia, antes da emenda 45 da Constituição Federal, a homologação de sentenças estrangeiras que há uma presunção de trânsito em julgado. Da mesma forma, havendo dúvida acerca de observância de formalidades, há uma presunção de que cabe ao Tribunal Superior Eclesiástico o cuidado no que concerne às observações das normas canônicas ${ }^{69}$.

Note-se ainda que os efeitos da declaração de nulidade matrimonial canônica, pelo Acordo, chancela a força do casamento canônico. Porém, essa circunstância não impede o divórcio, o que aparentemente não seria possível, observados os termos do Cân. 1055 que declara o matrimônio indissolúvel. Todavia, ao ser registrado no Registro Civil, assume a chancela do Estado, ficando ao amparo das leis nacionais.

Para o cidadão comum, fiel cristão, esse artigo do Acordo pode não ter maior repercussão tendo em vista o desconhecimento acerca dos termos do Acordo Brasil-Santa Sé. Aos religiosos, a questão é civil, para os civilistas, a questão tem interesse apenas para os crentes. $\mathrm{O}$ assunto tem ficado restrito à área acadêmica de Direito Canônico, aos tribunais eclesiásticos ${ }^{70}$ e Sociedade Brasileira de Canonistas ${ }^{71}$.

Certo é que as questões que advierem da aplicação do Acordo Brasil-Santa Sé, em especial no que se refere ao art. 12, dependerá do que for sendo construído em termos de jurisprudência canônica e da interpretação interna por parte do Superior Tribunal de Justiça a quem caberá a homologação da sentença estrangeira.

$\mathrm{Na}$ área puramente civil, segundo o art. 1548, inciso I, do Código Civil, a hipótese de nulidade é taxativa, considerando que foi revogada a primeira hipótese pela Lei 13.146/ 2015 (Estatuto da Pessoa com Deficiência), restando apenas uma: casamento contraído pelo enfermo mental sem o necessário discernimento para a prática dos atos da vida civil.

A discussão jurisprudencial era se haveria ou não necessidade de interdição, mas a posição prevalente é no sentido de que a interdição não cria a incapacidade, mas, sim, a alienação mental. A incapacidade absoluta restou apenas limitada aos menores de 16 anos. Essa é a única hipótese de nulidade de matrimônio na esfera do direito civil brasileiro, demais casos são de anulabilidade. Assim, não se cogita, na esfera civil, a nulidade por problema de vontade. Também não existe mais o curador de vínculo prevista no art. 222 do Código Civil de 1916, sendo indispensável tão somente a intervenção do Ministério Público por se tratar tanto a ação de nulidade como de anulabilidade de ação de estado.

Os efeitos da sentença da ação declaratória de nulidade são retroativos, ex tunc, observando o que dispõe o art. 1563 do Código Civil ${ }^{72}$, não podendo, todavia, prejudicar

\footnotetext{
${ }^{69}$ V.g. Sentença estrangeira 2041, com Ministro Antônio Neder como Relator, datado de, publicado em 5.3.75, onde consta dúvida acerca do trânsito em julgado e quanto à regular citação. Porém, a questão ficou superada porque entendeu o Tribunal ser responsabilidade do Superior Tribunal Eclesiástico verificar a regularidade procedimental.

${ }^{70}$ Foi encaminhada pela Suprema Assinatura Apostólica (Proc. no 39045/06 VAR) orientação aos Vigários Judiciais dos Tribunais Eclesiásticos do Brasil orientando acerca do requerimento do decreto executório para homologação ao Supremo Tribunal da Assinatura Apostólica e do requerimento a homologação ao Superior Tribunal de Justiça.

${ }^{71}$ No XXIV Encontro da Sociedade Brasileira de Canonistas, em Aracaju, de 13 a 18 de julho de 2009, o Acordo foi objeto de reflexão com palestras de Dom Hugo da Silva Cavalcante.

72 “Art. 1.563. A sentença que decretar a nulidade do casamento retroagirá à data da sua celebração, sem prejudicar a aquisição de direitos, a título oneroso, por terceiros de boa-fé, nem a resultante de sentença transitada em julgado".
} 
a aquisição de direitos, a título oneroso, por terceiro de boa-fé, nem o que resultar de sentença transitada em julgado. Ficam protegidos os institutos da boa-fé objetiva, o que adquiriu direitos com boa conduta e a coisa julgada ${ }^{73}$.

Portanto, considerando os efeitos da nulidade matrimonial, eventuais casos de homologação de sentença de nulidade canônica poderão provocar elementos a discutir, pois as situações de casamento sob coação moral (art. 1550, III $^{74}$ e $1558^{75}$, do Código Civil), ou por erro essencial quanto ao outro cônjuge (art. 1550, III, $1556^{76}$ e $1557^{77}$, do Código Civil), incapacidade de consentir e de manifestar de forma inequívoca a sua vontade (art. 1550, IV ${ }^{78}$, do Código Civil), além do casamento celebrado perante autoridade relativamente incompetente (art. 1150, VI, do Código Civil) são casos de anulabilidade, cujos efeitos de sentença são ex nunc. Vejamos, pois, que essas hipóteses poderiam ser facilmente colocadas em analogia ao que dispõem os Cân. 1095, 2º , 1097, $\S 1$ e e 2 ; $1101 ; \S 2$, do Código Canônico que, se comprovados, tornam consentimento inválido e nulo o matrimônio.

Note-se que a incapacidade de consentir prevista no art. 1550, IV, do Código Civil se refere aos alcoolistas, dependentes de drogas, não incidindo para as pessoas com discernimento mentais reduzidos e aos deficientes sem desenvolvimento completo. Essa alteração interpretativa se deu em virtude do Estatuto da Pessoa com Deficiência (Lei 13.146/2015). As pessoas com deficiência mental ou intelectual em idade núbil poderão contrair matrimônio civil, manifestando-se diretamente, pelo seu responsável ou curador. O objetivo é a inclusão social da pessoa com deficiência.

Uma discrepância relevante entre o ordenamento civil e canônico é que a anulabilidade do casamento não pode ser reconhecida de ofício pelo princípio da não intervenção. Portanto, não sendo proposta a ação anulatória nos prazos decadenciais ${ }^{79}$ previstos, o ato convalesce, passando a ser reputado válido ${ }^{80}$.

\section{PERSPECTIVAS}

O Estatuto da Igreja Católica é importante do ponto de vista jurídico de proteção à Igreja (bens culturais, tributário, proteção do clero) mas com pouca repercussão para o povo, com exceção à questão do ensino religioso confessional porque o matrimonial frente à legislação brasileira oferecerá dificuldades que só a jurisprudência dirá ou ficará uma letra morta sem muito uso.

Com relação ao ensino religioso, haverá necessidade de atenção da própria Igreja, colaborando na preparação de professores e de projetos que facilitem a relação fé e vida, superando caráter catequético e fortalecendo a responsabilidade pelo outro,

\footnotetext{
${ }_{73}^{73}$ TARTUCE, F. Direito de Família, p. 90.

${ }^{74}$ “Art. 1.550. É anulável o casamento: I - de quem não completou a idade mínima para casar; II - do menor em idade núbil, quando não autorizado por seu representante legal; III - por vício da vontade, nos termos dos arts. 1.556 a 1.558; IV - do incapaz de consentir ou manifestar, de modo inequívoco, o consentimento; V - realizado pelo mandatário, sem que ele ou o outro contraente soubesse da revogação do mandato, e não sobrevindo coabitação entre os cônjuges; VI - por incompetência da autoridade celebrante".

75 “Art. 1.568. Os cônjuges são obrigados a concorrer, na proporção de seus bens e dos rendimentos do trabalho, para o sustento da família e a educação dos filhos, qualquer que seja o regime patrimonial".

76“Art. 1.566. São deveres de ambos os cônjuges: I - fidelidade recíproca; II - vida em comum, no domicílio conjugal; III - mútua assistência; IV - sustento, guarda e educação dos filhos; V - respeito e consideração mútuos".

77 “Art. 1.567. A direção da sociedade conjugal será exercida, em colaboração, pelo marido e pela mulher, sempre no interesse do casal e dos filhos. Parágrafo único. Havendo divergência, qualquer dos cônjuges poderá recorrer ao juiz, que decidirá tendo em consideração aqueles interesses".

78“Art. 1.550. É anulável o casamento: [...] IV - do incapaz de consentir ou manifestar, de modo inequívoco, o consentimento".

${ }^{79} \mathrm{O}$ prazo decadencial para a propositura da ação de anulação nos termos do art. 1560 do Código Civil são: a) 180 dias, em relação aos incapazes de consentir ou manifestar; b) 2 anos, se realizado por autoridade incompetente de celebrar; c) 3 anos, no caso de erro essencial; d) 4 anos, se o casamento foi realizado mediante coação.

${ }^{80}$ Cf. TARTUCE, F. Direito de Família, p. 99.
} 
colaborando para relações fraternas, cooperativas, olhar com e para o outro, contribuindo na concretização da proposta evangélica do amor e da misericórdia.

A laicidade do Estado brasileiro é direito fundamental que confere a liberdade de expressão religiosa. Sem liberdade o conteúdo democrático de uma sociedade perde sentido.

A liberdade é direito de personalidade e, segundo o art. 11 do Código Civil, é intransmissível e irrenunciável. Ao discorrer sobre o tema expressão religiosa e direito fundamental, na VIII Jornada de Direito Civil, realizada no Conselho da Justiça Federal, em maio de 2018, o Ministro Luiz Edson Fachin trouxe a doutrina de Canotilho destacando: "A liberdade de religião é a liberdade de adotar ou não uma religião, de escolher uma determinada religião, de fazer proselitismo num ou noutro sentido, de não ser prejudicado por qualquer posição ou atitude religiosa ou antirreligiosa" ${ }^{\text {" }}$.

Portanto, a laicidade do Estado não impede que avancemos, embora nos desafie. Para isso, é preciso aumentar os laços afetivos do povo cristão com a sua Igreja, com a sua fé e preparar a juventude para atuar em uma sociedade plena de dificuldades. Em decorrência da carência de saúde, educação, violência, ausência de política públicas eficazes, aumenta a exigência aos leigos católicos. A Igreja não pode se omitir às questões dos excluídos, dos doloridos, dos encarcerados, não de forma tímida, mas com fervor de quem abraça o leproso, de quem não acolhe o pecado, mas o pecador.

O atuar da Igreja não será limitado pela secularização, laicidade e nem mesmo pelo laicismo que são apenas sinais dos tempos a alertar a necessidade da Igreja renovar as formas de evangelização especialmente nas cidades (pastoral urbana), com o uso adequado das mídias, de acordo com o Estudos 111 da $\mathrm{CNBB}^{82}$.

O fortalecimento do laicato exigirá uma constante atualização e religiosidade madura, sedimentada no diálogo interno que dê suporte ao enfrentamento no Estado sem tibieza e para isso é preciso formatar a base na infância e juventude e/ou propiciar formação continuada aos leigos.

É necessário ocupar espaços na ciência e política. Os sujeitos eclesiais não poderão se omitir às possibilidades de voz e vez nas situações que envolvam o bem comum e os valores da identidade cristã, proteção primordial à vida com dignidade de filhos de Deus, suprindo o vácuo ético.

A conversão pastoral nas exigências do Documento de Aparecida propõe uma renovação missionária ultrapassando estruturas que não favorecem a transmissão da fé (n. 365) com vários desafios, observando os sinais dos tempos: laicismo estatal, secularização nas relações, enfraquecimento de laços pessoais e crise ética na política.

É possível propor algumas ações: fortalecer o sentimento de pertença, motivando a uma efetiva atuação política; promover a transparência nas relações internas e compromisso social, desenvolvendo a pedagogia da convivência/cooperação nas relações em constante conversão com a prevalência de ações que visem ao bem comum e à dignidade humana na busca da santificação pessoal e comunitária.

E mais, é urgente a promoção de ações pastorais que visem não só à conversão pessoal, mas social, na defesa da ética e alteridade, com o olhar voltado especialmente aos excluídos, aos marginalizados: encarcerados, dependentes, população de rua e migrantes e os pobres da Palavra.

Os textos publicados pela Igreja no Brasil são fontes de conhecimento e de fortalecimento na ação (Documento de Aparecida, Documentos da CNBB 100, 105 e 106).

${ }^{81}$ GOMES CANOTILHO, J.J. et al. Constituição da República Portuguesa Anotada, p. 609, apud FACHIN, L. E. Direito Fundamental e Expressão Religiosa, p. 13.

${ }^{82} \mathrm{Cf}$. CNBB, Orientações Pastorais para as Mídias Católicas Imprensa, rádio, TV e novas mídias. 
O Papa Francisco tem sido incansável na sua missão, voltando um olhar misericordioso ao povo de Deus. Destaquem-se os documentos mais recentes do Papa Francisco: Exortação Apostólica Pós Sinodal Amoris Laetitia e Exortação Apostólica Gaudete et Exultate, chamamento à santidade que não se esgota na crítica aos inimigos sutis da santidade como o gnosticismo atual, tratamento da doutrina, como se essa pudesse desvelar o mistério e os ensinamentos da Igreja frequentemente esquecidos (Cap. II), mas indicando como a grande regra de comportamento a misericórdia ${ }^{83}$.

"Não podemos propor-nos um ideal de santidade que ignore a injustiça deste mundo" "84. Para isso, é necessário coragem e construir um movimento consciente de pacificação que não significa omissão, mas o uso das habilidades de comunicação de forma não violenta e de diálogo, iniciando por nós, "atentos ao mundo com o coração imerso em Deus", conforme apontou o Papa na Mensagem aos participantes no Congressos dos Institutos Seculares que nos sugere comportamentos espirituais: rezar, discernir, partilhar, encorajar e sentir simpatia pelo mundo e pelas pessoas, que vem do Espirito e nos torna livres e apaixonados.

Mas, junto à "simpatia", é importante desenvolvermos a "empatia", colocando-nos no lugar do outro, promovendo a transformação social ${ }^{85}$.

Não somos cegos e temos discernimento para ver e julgar, conforme demonstram os documentos recentes da CNBB e manifestações do Papa Francisco. Impõe-se, contudo, agir e, para que isso ocorra, é preciso ter amor, adotando uma conduta responsável, comprometida e perseverante no exercício da missão evangelizadora, pelo testemunho, fazendo constante movimento de avaliação. Tenhamos a coragem de seguir avante sem desanimar, confiantes nas palavras de Jesus: "Eis que estou com vocês todos os dias, até o fim do mundo" (Mt 28,20).

\section{REFERÊNCIAS}

V CONFERÊNCIA GERAL DO EPISCOPADO LATINO-AMERICANO E DO CARIBE, Aparecida. Documento de Conclusão, São Paulo 2007.

ACORDO ENTRE A REPÚBLICA FEDERATIVA DO BRASIL E A SANTA SÉ RELATIVO AO ESTATUTO JURÍDICO DA IGREJA CATÓLICA NO BRASIL. Decreto no 7.107, 11.02.2010. Disponível em: <http://www.planalto.gov.br/ccivil_03/_Ato2007-2010/2010/Decreto/D7107>. Acesso em: 01 jul. 2010.

ALBERTON, G. da S. Laicidade na relação Igreja-Estado e o Acordo Brasil-Santa Sé. Curitiba: Prismas, 2015.

ARROBA CONDE, M. Direito processual canônico. 5. ed. Roma: Institutum Iuridicum Claretianum, 2006.

AZEVEDO, R. O IBGE e a Religião. Revista Veja, 29 junho 2012. Disponível em: <https://veja. abril.com.br/blog/reinaldo/o-ibge-e-a-religiao-cristaos-sao-86-8-do-brasil-catolicos-caem-para-646-evangelicos-ja-sao-22-2/>. Acesso em: 20 ago. 2018.

BALDISSERI, L. Diplomacia Pontifícia-Acordo Brasil-Santa Sé. Intervenções. São Paulo: LTr, 2011. BOBBIO, N. et al. Dicionário de Política. 7. ed. Brasília: UNB, 2000. v. II.

BORJA, C. Constitucionalidade do art. 11 do Acordo Brasil-Santa Sé. In: BALDISSERI, L.; MARTINS FILHO, I. G. (Coord.). Acordo Brasil-Santa Sé comentado. São Paulo: LTR, 2012. p. 300-325.

BRASIL. Constituição Federal de 1988. 4. ed. São Paulo: Oliveira Mendes, 1999.

\footnotetext{
${ }^{83}$ Cf. FRANCISCO, Gaudete et exsultate, n. 95.

${ }^{84} \mathrm{FRANCISCO}$, Gaudete et exsultate, n. 101.

${ }^{85}$ Cf. KRZNARIC, R. O Poder da Empatia: a arte de se colocar no lugar do outro para transformar o mundo. Rio de Janeiro: Zahar, 2015.
} 
BRASIL. Código Civil - Lei no 10.406, de 10 de janeiro de 2002. São Paulo: Revista dos Tribunais, 2002.

Código de Processo civil, Lei no 13.105, de março de 2015. Disponível em: <http://www. planalto.gov.br/ccivil_03/_Ato2015-2018/2015/Lei/L13105.htm>. Acesso em: 15 jan. 2016.

CARVALHO LEITE, F. O laicismo e outros exageros sobre a Primeira República no Brasil. Religião e Sociedade, Rio de Janeiro, v. 35, n. 1, junho 2011. Disponível em: <http://www.scielo.br/scielo. php?script=sci_arttext\&pid=S0100-85872011000100003>. Acesso em: 20 ago. 2018.

CATROGA, F. Entre deuses e césares: secularização, laicidade e religião civil: uma perspectiva histórica. Coimbra: Almedina, 2006.

CLARO, D. Vamos defender a vida: convoca Dom Ricardo Hoepers sobre aborto. Notícias Canção Nova. Cachoeira Paulista (22.06.2018). Disponível em: <https://noticias.cancaonova.com/brasil/ vamos-defender-a-vida-convoca-dom-ricardo-hoepers-sobre-aborto/>. Acesso em: 20 ago. 2018.

CÓDIGO DE DIREITO CANÔNICO. Promulgado por João Paulo II, papa. Trad. Conferência Nacional dos Bispos do Brasil. São Paulo: Loyola, 1987.

CNBB. Diretrizes gerais da Ação Evangelizadora na Igreja no Brasil 2015-2019. São Paulo: Paulinas, 2015.

Orientações pastorais para as mídias católicas imprensa, rádio, TV e novas mídias. Brasília, 2018. (Estudos da CNBB, 111).

DINIZ, D.; LIONÇO, T. Educação e laicidade. In: DINIZ, D.; LIONÇO, T.; CARRIÃO, V. Laicidade e ensino religioso no Brasil. Brasília: UNESCO; Letras Livres; Fundação Universidade de Brasília; Editora UNB, 2010. p. 12-50.

DINIZ, D.; LIONÇO, T.; CARRIÃO, V. Laicidade e ensino religioso no Brasil. Brasília: UNESCO; Letras Livres; Fundação Universidade de Brasília; Editora UNB, 2010.

DOLINGER, J. Direito internacional privado. 4. ed. Rio de Janeiro: Renovar, 1997.

FACHIN, L. E. Direito Fundamental e Expressão Religiosa. In: Justiça\&Cidadania, p. 13, 20 jun. 2018.

FAZIO, M. Storia delle idee contemporanee: una lettura del processo di secolarizzazione. [s.d. s.1.].

La autonomia de las realidades terrestres en la Gaudium et Spes. Teocomunicação, Porto Alegre, v. 35, n. 150, p. 639-655. dez. 2005.

FINOCCHIARO, F. Dirito ecclesiastico. Bolonha: Zanichelli, 2017.

FRANCISCO. Exortação apostólica pós-Sinodal Evangelii Gaudium. Disponível em: <https:// w2.vatican.va/content/francesco/pt/apost_exhortations/documents/papa-francesco_esortazioneap_20131124_evangelii-gaudium.html>.

Carta encíclica Laudato Sì sobre o cuidado da casa comum (24.05.2015). Disponível em:

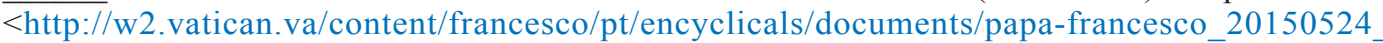
enciclica-laudato-si.html>.

Mensagem aos participantes no congresso dos institutos seculares italianos por ocasião da constituição apostólica Provida Mater Ecclesia (23.10.2017). Disponível em: <papafrancesco_20171023_messaggio-conferenza-italiana-istituti-secolari.pdf>. Acesso em: 20 ago. 2018.

Exortação apostólica Gaudete et exsultate sobre o chamado à santidade no mundo atual (19.03.2018). São Paulo: Paulinas, 2018.

GIUMBELLI, E. O fim da Religião - dilemas da liberdade religiosa no Brasil e na França. São Paulo: Attar Editorial, 2002.

GOMeS CANOtilho, J. J. et al. Constituição da República Portuguesa anotada. v. I. 4. ed. Coimbra: Coimbra Editora, 2007.

INTROVIGNE, M. Tu sei Pietro. Benedetto XVI contro la dittatura del relativismo. Milano: Sugarco, 2011.

JOÃO PAULO II. Discurso inaugural da III Conferência Geral do Episcopado Latino-Americano em Puebla (28.01.1979). Disponível em: <http://w2.vatican.va/content/john-paul-ii/pt/speeches/1979/ january/documents/hf_jp-ii_spe_19790128_messico-puebla-episc-latam.html>. 
JOÃO PAULO II. Discurso inaugural da IV Conferência Geral do Episcopado Latino-Americano e Caribenho em Santo Domingo (12.10.1992). Disponível em: <http://w2.vatican.va/content/john-paulii/pt/speeches/1992/october/documents/hf_jp-ii_spe_19921012_iv-conferencia-latinoamerica.html>.

KRZNARIC, R. O Poder da Empatia: a arte de se colocar no lugar do outro para transformar o mundo. Rio de Janeiro: Zahar, 2015.

LIPOVETSKY, G. A era do vazio: ensaios sobre o individualismo contemporâneo. São Paulo: Manole, 2005.

LOBO, P. O Estado laico é conquista de todos e das famílias. Revista Consultor Jurídico, São Paulo, 06.12.2015. Disponível em: <https://www.conjur.com.br/2015-dez-06/processo-familiar-estadolaico-conquista-todos-familias>. Acesso em: 20 ago. 2018.

LÖWY, M. A guerra dos deuses: religião e política na América Latina. Rio de Janeiro: Vozes, 2000.

MONROY, P. A. Eficácia civil de las sentencias eclesiásticas matrimoniales. Disponível em: $<$ http:www.am.abogados.com/blog>. Acesso em: 21 mar. 2011.

OLIVEIRA, H. J. S. C. Art. 2o Direito de Desempenhar a Missão Apostólica. In: BALDISSERI, L.; MARTINS FILHO, I. G. (Coord.). Acordo Brasil-Santa Sé comentado. São Paulo: LTR, 2012. p. 107-136.

POSSENTI, V. Le ragioni della laicità. Soveria Mannelli [Calabria]: Rubbettino, 2007.

SANDRINI, M. Ensino Religioso e Educação Humanista num Estado Leigo [arquivo pessoal].

SAVAGNONE, G. Dibattito sulla laicità: alla ricerca di una identità. Turim: Elledici, 2010.

SENADO FEDERAL. Lei de Diretrizes e Bases da Educação Nacional. Brasília, 2005. Disponível em: < https://www2.senado.leg.br/bdsf/bitstream/handle/id/70320/65.pdf>. Acesso em: 20 jul. 2018.

SMITH, W. C. O sentido e o fim da religião. São Leopoldo: Sinodal, 2015.

SOUZA, S. C. de. A Santa Sé e o Estado da Cidade do Vaticano: distinção e complementaridade. Revista da Faculdade de Direito da Universidade de São Paulo, v. 100, p.287-314. jan.-dez. 2005. https://doi.org/10.11606/issn.2318-8235.v100i0p287-314

SUPREMO TRIBUNAL FEDERAL. Acordo Brasil-Santa Sé - ADI 4439. Disponível em: <http:// redir.stf.jus.br/estfvisualizadorpub/jsp/consultarprocessoeletronico/ConsultarProcessoEletronico.js f? seqobjetoincidente=3926392>. Acesso em: 17 nov. 2011.

TALAMINI, E. Coisa julgada e sua revisão. São Paulo: Revista dos Tribunais, 2005.

TARTUCE, F. Direito de Família. 11. ed. Rio de Janeiro: Forense, 2016.

TAYLOR, C. Uma era secular. São Leopoldo: Ed. UNISINOS, 2010.

Recebido em: 07/11/2018

Aprovado em: 22/11/2018

Correspondência para:

Desa. Genacéia da Silva Alberton

5a Câmara Criminal Tribunal de Justiça do Estado do Rio Grande do Sul

Av. Borges de Medeiros, 1565

CEP 90110-906 Porto Alegre, RS, Brasil 